денної, заочної та дистанційної форм навчання усіх напрямів підготовки). Харків. нац. ун-т міськ. госп-ва ім. О.М. Бекетова ; уклад. : Н. В. Козирєва. Харків: ХНУМГ ім. О.М. Бекетова, 2018. 69 с.

6. Формуємо у старших дошкільників цілісне світобачення: навчально-методичний посібник / Кононко О.Л. та ін. К. : «Імекс-ЛТД». $260 \mathrm{c}$.

7. Якименко C.I. Формування світогляду у старших дошкільників та молодших школярів в освітньо-інтегрованому середовищі: теорія $\mathrm{i}$ практика: монографія. К. : СЛОВО, 2017. 640 с.

DOI https://doi.org/10.30525/978-9934-588-80-8-1.58

\title{
ІНФОРМАЦЙНО-КОМУНІКАЦІЙНІ ТЕХНОЛОГІЇ У ПРАКТИЦІ РОБОТИ СУЧАСНОГО ВЧИТЕЛЯ ПОЧАТКОВИХ КЛАСІВ
}

\author{
Мотуз Т. В. \\ кандидат педагогічних наук, \\ доцент кафедри загальної, спеціальної педагогіки, реабілітації \\ та інклюзивної освіти \\ КЗВО «Дніпровська академія неперервної освіти» \\ Дніпропетровської обласної ради \\ Мотуз Т. Ю. \\ вчитель початкових класів, \\ Павлівська філія I ступеня \\ КОЗО «Новопокровський заклад загальної середньої освіти» \\ м. Дніпро, Украӥна
}

Метою роботи $є$ обгрунтування та аналіз застосування інформаційно-комунікаційних технологій $\mathrm{y}$ практиці роботи вчителя початкових класів. Актуальність застосування інформаційно-комунікаційних технологій в діяльності вчителя початкових класів зумовлено низкою чинників, серед яких виділяємо:

- виникнення та розвиток інформаційного суспільства;

- цифровізація вітчизняної системи освіти, зокрема початкової;

- упровадження компетентісного підходу в освіті як ключового, про що наголошується у Концепції Нової української школи [2] та Державному стандарті початкової освіти [3]; 
- оновлені вимоги до професійної компетентності вчителя, що окреслені в професійному стандарті «Вчитель початкових класів закладу загальної середньої освіти», зокрема здатність вчителя добирати оптимальні форми організації освітнього процесу та форми взаємодії його учасників, створювати сучасне інноваційне освітне середовище та ін. [4].

Компетентісний потенціал освітніх галузей передбачає організацію процесів навчання та виховання учнів початкових класів із використанням різноманітних форм, методів, засобів і технологій. Одними 3 таких ефективних і перспективних технологій вважаємо інформаційно-комунікаційні. Інформаційно-комунікаційні технології (IКT) - засоби, пов'язані зі створенням, збереженням, передачею, обробкою і управлінням інформації [1]. Цей широко вживаний термін включає в себе всі технології, що використовуються для комунікації та роботи з інформацією.

Доцільність використання ІКТ у початковій школі зумовлено такими факторами:

1) вік учня початкової школи є важливим етапом у розвитку дитини, що пов'язаний з початком навчання в школі, зміною основного виду діяльності з ігрової на навчальну;

2) відбувається формування набору життєвих пріоритетів, що відбувається в процесі сприйняття складних соціальних взаємозв'язків і механізмів та пошуку свого місця в системі соціальних ролей i інститутів;

3) це період інтенсивного розвитку мови, мислення, пам'яті, уваги, сприйняття, самосвідомості.

Цілі використання ІКТ вчителем початкових класів:

- формування початкової комп'ютерної грамотності та елементів інформаційної культури учнів;

- оволодіння практичними способами роботи з інформацією: пошук, аналіз, перетворення, передача, зберігання інформації, іії використання в навчальній діяльності та повсякденному житті;

- виховання інтересу до інформаційної та комунікаційної діяльності, етичних норм роботи з інформацією, дбайливого ставлення до технічних пристроїв;

- оволодіння вміннями використовувати комп'ютерну техніку для роботи з інформацією в навчальній діяльності та повсякденному житті.

Використання ІКТ на різних уроках у початковій школі дозволяє:

- розвивати вміння учнів орієнтуватися в інформаційних потоках навколишнього світу;

- опановувати практичні способи роботи з інформацією; 
- розвивати вміння, що дозволяють обмінюватися інформацією за допомогою сучасних технічних засобів.

Сучасні ІКТ дозволяють вчителю значно розширити можливості подачі різного типу інформації. При дидактично правильному підході ІКТ активізують увагу учнів, їх мотивацію, розвивають пізнавальні процеси: мислення, уяву і фантазію.

Інформаційні технології можуть зробити процес навчання більш цікавим, таким, що відповідає вимогам сьогодення, надаючи потрібну інформацію в потрібний час. Через використання в освітньому процесі ІКТ реалізується діяльнісний підхід, пізнавальна діяльність дитини організовується в зручній формі, таким чином забезпечується індивідуальний диференційований підхід до процесу навчання.

Основні форми застосування ІКТ у навчальні діяльність учнів початкових класів зображено на рис. 1.

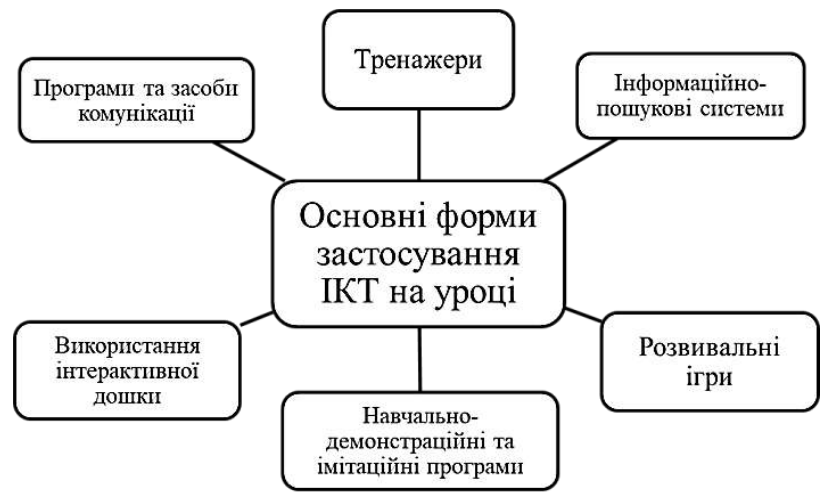

Одним із перспективних і ефективних засобів ІКТ у початковій школі вважаємо інтерактивну дошку. Інтерактивна дошка - це гнучкий інструмент, що поєднує простоту звичайної маркерної дошки 3 можливостями комп'ютера. У комбінації 3 мультимедійним проектором вона стає великим інтерактивним екраном, одним дотиком руки до поверхні якого можна відкрити будь-який комп'ютерний додаток або сторінку в Інтернеті й демонструвати потрібну інформацію або просто малювати. Працюючи 3 інтерактивною дошкою, учні засвоюють інформацію не тільки через аудіальний і візуальний канали сприйняття, але й через кінестетичний канал.

Сучасні моделі інтерактивних дошок мають у комплекті спеціальне програмне забезпечення, за допомогою якого можна створювати уроки, 
що містять низку інтерактивних вправ для учнів. Програмне забезпечення для створення уроків дозволяє вбудовувати інтерактивні вправи, анімацію, QR-коди, колажі та ін. Такий простий i швидкий доступ до інформації змушує учнів міркувати й створювати нові ідеї.

Однією 3 переваг використання інтерактивної дошки на уроці $є$ великий екран, на який проектується інформація, яку видно кожному, i вчитель має змогу заволодіти увагою всього класу. Школярі бачать великі кольорові зображення і діаграми, взаємодіють 3 матеріалом, пересуваючи букви, числа, слова і картинки. Одним тільки пальцем учень може працювати з різноманітними фігурами, шукати потрібну інформацію в мережі або робити презентацію, а за допомогою маркера, що знаходиться на спеціальній підставці, він пише на екрані електронним чорнилом.

Отже, використання інтерактивної дошки робить заняття цікавими й розвиває мотивацію, надає більше можливостей для участі в колективній роботі, розвитку особистих і соціальних навичок.

Отже, на підставі вищевикладеного можна зробити висновок, що основні переваги використання IКТ на уроках у початковій школі:

- дають можливість використовувати інтернет-сервісів і ресурсів як опорну підтримку всіх видів діяльності;

- забезпечують поєднання текстової, аудіо- та відео-наочності;

- сприяють розвитку креативних здібностей учнів;

- забезпечують здійснення контролю за засвоєнням нових знань i систематизації вивченого матеріалу.

\section{Література:}

1. Биков В.Ю. Моделі організаційних систем відкритої освіти: [монографія]. К.: Атіка, 2009. 684 с.

2. Концепція нової української школи. URL : https://mon.gov.ua/ua/ osvita/zagalna-serednya-osvita/nova-ukrayinska-shkola

3. Про затвердження Державного стандарту початкової освіти: постанова Кабінету Міністрів України від 21.02.2018 p. № 87. URL: https://zakon.rada.gov.ua/laws/show/87-2018-\%D0\%BF\#Text

4. Про затвердження професійного стандарту «Вчитель початкових класів закладу загальної середньої освіти»: наказ Міністерства соціальної політики України України (2018, серп. 10). Наказ № 1143 від 10.08.2018. URL: https://zakon.rada.gov.ua/rada/show/v1143732-18 